\title{
Evaluation Model for CAI Courseware based on Intuitionistic Fuzzy Theory
}

\author{
Liu Hong-yan \\ School of Journalism and Communication \\ Lanzhou University of Arts and Science \\ Lanzhou, China \\ liu_h_y@126.com
}

\begin{abstract}
Aiming at the defects and deficiencies of the current assessment of teaching evaluation of Computer Assisted Instruction (CAI) courseware, combined with existing evaluation methods and norm system of CAI courseware, a comprehensive evaluation model for multimedia CAI courseware was proposed in this paper which based on intuitionistic fuzzy theory. Intuitionistic fuzzy theory is a kind of effective method which dealing with uncertain information by using membership functions and non-membership functions. It can evaluate the multimedia CAI courseware objectively, efficiently and accurately, thereby reducing the uncertainty and human interference factors in the evaluation of CAI courseware, and providing effective protection and support for the development and use of multimedia CAI courseware and assurance of teaching quality. Finally, some specific cases have been given to analyze the proposed model.
\end{abstract}

Keywords-intuitionistic fuzzy theory; multimedia CAI courseware; evaluation principles; evaluation model

\section{INTRODUCTION}

With the popularization of modern educational technology in teaching, the role of computers in modern education is growing, on this basis, a new subject area is formed which called computer-assisted instruction. Computer-assisted instruction (CAI) is the use of computer to integrate text, graphics, images, sound, animation, video and other form of media together, and stored them in a computer program, which is a comprehensive technology. CAI courseware is the organic organization of variety of media, which give students intuitive stimulation on vision, hearing and other organs, and can improve the interest of student in learning, increase the amount of information of class, animate the teaching atmosphere, beneficial the comprehensive development of students. It is the most optimized teaching system and has broad application prospects and great potential development.

It is an important research topic that how to evaluate multimedia CAI courseware effectively reasonably and accurately. For the designers and producers of multimedia teaching, effective evaluation can help developers to find problems and improve or enhance the quality of multimedia CAI courseware continuously. For users, it helps to discard the dross and select the essential effectively, choose the resources reasonable, and improve the teaching level. However, current CAI coursewares on various areas, due to various reasons, still have many problems on their quality. Since multimedia CAI courseware is an interdisciplinary integrated with computer science, art, education, psychology and other subjects, its evaluation is a systematic project and multi-objective decision making problem. Currently, many evaluation of multimedia CAI coursewares are qualitative evaluations, and these evaluations have a lot of subjectivity and human factors, evaluation results are often inaccurate or have contrary to the objective laws sometimes, or even wrong. Such evaluations will result in incorrect judgment of policy makers, bring error message to teaching evaluation, and finally lead to wrong decisions. Therefore, it is absolutely necessary to discuss how to establish a scientific, rational and complete evaluation system and measurement standard for CAI coursewares, and it is also an important research topic placed in front of educators. Although there are some research results about evaluation of multimedia CAI coursewares ${ }^{[3-10]}$, and some of them have its scientific principles, these methods still have some flaws and shortcomings.

Based on the research work mentioned above, combined with the analysis of factors that affect the quality of CAI coursewares, the paper constructed a new evaluation model for CAI coursewares on the basis of intuition fuzzy theory, and carried out quantitative evaluation and analysis, which can be a better solution for the evaluation of multimedia CAI coursewares.

\section{INTUITIONISTIC FUZZY THEORY}

Intuitionistic fuzzy theory (IFT) ${ }^{[11]}$ is a kind of fuzzy concept proposed by Professor Atanassov in 1983, which is the promotion and extension of classic Zadeh fuzzy mathematics. Intuitionistic fuzzy theory taking the real membership, fake membership and hesitation into consideration at the same time, and describe the uncertainty and vagueness of information through the real membership, fake membership and hesitation.

Definition $1^{[12]}$ :Suppose $X$ is the given universe, call $A=\left\{\left\langle x, \mu_{A}(x), v_{A}(x)\right\rangle \mid x \in X\right\}$ the intuitionistic fuzzy set, marked as $\operatorname{IFS}(X) . \quad v_{A}(x): X \rightarrow[0,1], \mu_{A}(x): X \rightarrow[0,1]$ represent the membership and non-membership of element $x$ belong to $X$, and satisfied $0 \leq \mu_{A}(x)+v_{A}(x) \leq 1, x \in X$. Besides, call $\pi_{A}(x)=1-\mu_{A}(x)-v_{A}(x)$ the hesitation of $X$ 
belong to $A$. For convenience, denote the intuitionistic fuzzy numbers as $\left(\mu_{A}(x), v_{A}(x)\right)$.

Intuitionistic fuzzy theory represents the support, against and neutral degree of intuitionistic fuzzy set $A$ to evidence by setting up the real membership, fake membership and hesitation. Science people's understanding of things in objective reality is always incomplete and not comprehensive, which result in the subjectivity and ambiguity when people understand the objective phenomenon. Therefore, it is a feasible and effective method to deal with uncertainty problem with intuitionistic fuzzy theory. Meanwhile, characterize the understanding and expression of the subject to the object by intuitionistic fuzzy is a basic cognitive thinking way of information processing. Quantitative and qualitative information provided by intuitionistic fuzzy theory to the subject is necessarily related with the receive, process, use of cognitive level of the subject, therefore, processing information by intuitionistic fuzzy theory not only has determined side but also has uncertainty side.

\section{PRINCIPLES AND STANDARDS FOR CAI COURSEWARE EVALUATION}

In order to evaluate CAI multimedia coursewares, we must firstly set up a reasonable evaluation index system. Evaluations of multimedia CAI courseware not only need to achieve the evaluation target, but also need to reflect the quality requirements of the CAI teaching objects. When establishing the evaluation index of CAI courseware, it must follow the necessary evaluation principles. In this paper, combined with the experience on the development of teaching CAI courseware and some feedback information, we put forward the following principles.

\section{A. Principles of scientific and teaching}

As a computer assisted teaching software, the evaluation system of CAI courseware must be scientific, correct and correspond with the regular pattern and requirements of teaching. It is able to reflect the key elements restrict and influence teaching, and the establishment of evaluation index must reflect the scientific and pedagogic of teaching evaluation.

\section{B. Objectives and orientation}

The evaluation index of CAI courseware has to be consistent with teaching objectives and can reflect the requirements of teaching, guide and improve the teaching by CAI according to the needs of teaching.

\section{Integrity and development}

Evaluation index of CAI courseware has to reflect the objectives and management of teaching comprehensively, systematically, completely and efficiently, for the important teaching index, evaluation has to be completely, non of the important indicator can be lost. At the same time, teaching indicators should be established on the basis of a metabolic, coordinated, continuable and organic link.

\section{Feasibility and Operability}

Evaluation index of CAI courseware not only need to be feasible, but also need to have operability, under the premise of reflect the requirements of teaching, it has to be facilitate for operation, be acceptable to both of the parties of evaluator and evaluated, and can better reflect the fairness and rationality.

\section{E. Testability and comparable}

The established evaluation can be reflected by actual measurement, quantification or qualitative operation, and the results of evaluation can be compared.

All in all, the establishment of CAI courseware index is an interdisciplinary involved education, computer science, psychology and other disciplines. It has to be done after a comprehensive, objective and reasonable consideration of the actual situation of developers, users and educators, and has to meet the transmission theory, learning theory and systems theory of teaching. Due to different cognitive level, education level, environment and actual circumstances, different CAI courseware developer may design different multimedia courseware, and its focus is quite different too. It is feasible to use questionnaire or multivariate statistical methods for data collection and processing, so that to establish a relatively scientific and reasonable evaluation index system for CAI courseware.

\section{Proposed Evaluation System For CAI COURSEWARE}

After a comprehensive consideration of pedagogy, psychology, education design, technical, artistry and other aspects, the paper established a new evaluation system for CAI courseware (shown in Table 1).

\section{A. Teaching content}

Teaching content is an important indicator of CAI courseware must be followed, including the scientific standardization, architecture knowledge, reasonable arrangements for the teaching content of teaching resources and so on.

\section{B. Teaching design}

Teaching design is the rational design and arrangement of the target tissue and learning environment of multimedia courseware, specifically including the indicators such as target design, content organization, interactive of teaching, practice and evaluation of learning, etc. The design should reflect a good human-computer interaction, and a good humancomputer interaction is mainly reflected in ease of use, responsiveness, and so on. Specifically, it is realized by some buttons, menus, interactions, dialog, forms, tabs, toolboxes, scroll bars, etc.

\section{Technical}

Technical mainly reflect the choice of producers on development tools, operating environment and design of interaction, it also reflect the development, design and 
application of related multimedia (such as voice, images, video, animation, etc.).

TABLE I. PROPOSED EVALUATION SYSTEM AND INDEX

\begin{tabular}{|c|c|c|}
\hline First Class Evaluation Index & Second Class Evaluation Index & Third Class Evaluation Index \\
\hline \multirow{3}{*}{ Education Content } & scientific & rationality \\
\hline & knowledge system & $\begin{array}{l}\text { knowledge coverage } \\
\text { reflects of structure }\end{array}$ \\
\hline & resources applications & resources situation resources utilize \\
\hline \multirow{2}{*}{ Education Design } & target organization & $\begin{array}{c}\text { target design } \\
\text { content organization }\end{array}$ \\
\hline & learning environment & $\begin{array}{l}\text { interactive teaching } \\
\text { learning assessment }\end{array}$ \\
\hline \multirow{2}{*}{ Technical } & operational state & $\begin{array}{l}\text { operating environment } \\
\text { operating conditions }\end{array}$ \\
\hline & design effect & $\begin{array}{c}\text { utilize of Software } \\
\text { design level } \\
\text { application of media }\end{array}$ \\
\hline \multirow{2}{*}{ Artistry } & interface design & $\begin{array}{l}\text { effects of interface } \\
\text { effect of art }\end{array}$ \\
\hline & media effects & $\begin{array}{l}\text { selection of media } \\
\text { design of media }\end{array}$ \\
\hline
\end{tabular}

\section{Artistry}

Artistry mainly includes the design of interface and artistic effect. Interface design should highlight the theme and the most important information, so it is better to be rational layout, lively, novel, beautiful, and full of artistic effect and infectant power, the color of screen has to be balance and harmony, as the quality of color can directly reflect the content of the focus, heighten the atmosphere.

\section{EVALUATION OF CAI COURSEWARE BASED ON INTUITIONISTIC FUZZY THEORY}

\section{A. Intuitionistic fuzzy evaluation method}

For the intuitionistic fuzzy number $\left(\mu_{A}(x), v_{A}(x)\right)$, in order to reflect the rationality and effectiveness of decision objectively, the first thing is to determine the weight value of property indicator. According to human thinking and cognitive intuition: the larger the value of $\mu_{A}(x)-v_{A}(x)$, the better the decision-making results are; the smaller the value of $\pi_{A}(x)$, the better the decision-making results are. Therefore, we can setup a multi-objective optimization model:

$$
\left\{\begin{array}{c}
\max \omega=\sum_{i=1}^{n} \omega_{i}\left(\mu_{A i}(x)-v_{A i}(x)\right) \\
\min \omega=\sum_{i=1}^{n} \omega_{i} \pi_{A i}(x) \\
\text { s.t } \omega_{i}=W, \quad \sum_{i=1}^{n} \omega_{i}=1, \omega_{i} \geq 0
\end{array}\right.
$$

Meanwhile, in order to ensure the rationality and effectiveness of decision-making model, model (1) can be further optimized to form a single objective optimization model as follows:

$$
\left\{\begin{array}{c}
\max \omega=\sum_{i=1}^{n} \omega_{i}\left(\mu_{A i}(x)-v_{A i}(x)-\pi_{A i}(x)\right) \\
\text { s.t } \omega_{i}=W, \quad \sum_{i=1}^{n} \omega_{i}=1, \omega_{i} \geq 0
\end{array}\right.
$$

Specific process and steps of the method is shown as below:

Step 1: Set up optimization model based on the intuitionistic fuzzy attribute decision matrix.

Step 2: Solving the optimization model and calculate the weight value $w_{i}$ of attributes. 
Step 3: Carry out information aggregation on the value of attributes using OWA operator ${ }^{[14]}$, to get the comprehensive aggregated value of attributes $e_{i}$.

Step 4: Compare the value of the attributes $e_{i}$, therefrom to sort or select a better one.

\section{B. Application of intuitionistic fuzzy evaluation method}

There are 4 existing CAI coursewares $X_{1}, X_{2}, X_{3}$ and $X_{4}$, and intuitionistic fuzzy decision matrix is shown in Table 2 through expert assessment survey and argumentation.

TABLE II. INTUITIONISTIC FUZZY DECISION MATRIX FOR A CAI COURSEWARE EVALUATION EXAMPLE

\begin{tabular}{|c|c|c|c|c|}
\hline Courseware & $\begin{array}{c}\text { Education } \\
\text { Content }\end{array}$ & $\begin{array}{c}\text { Education } \\
\text { Design }\end{array}$ & $\begin{array}{c}\text { Technical } \\
\text { Index }\end{array}$ & $\begin{array}{c}\text { Artistry } \\
\text { Index }\end{array}$ \\
\hline $\mathrm{X}_{1}$ & $(0.3,0.4)$ & $(0.6,0.2)$ & $(0.2,0.6)$ & $(0.2,0.6)$ \\
\hline $\mathrm{X}_{2}$ & $(0.6,0.2)$ & $(0.4,0.5)$ & $(0.4,0.3)$ & $(0.4,0.4)$ \\
\hline $\mathrm{X}_{3}$ & $(0.4,0.5)$ & $(0.4,0.4)$ & $(0.4,0.5)$ & $(0.6,0.3)$ \\
\hline $\mathrm{X}_{4}$ & $(0.5,0.2)$ & $(0.3,0.5)$ & $(0.6,0.2)$ & $(0.4,0.2)$ \\
\hline
\end{tabular}

From Table 2 we can get the decision matrix of intuitionistic fuzzy value $\mu_{A i}(x)-v_{A i}(x)-\pi_{A i}(x)$ for the 4 CAI courseware:

$$
\xi=\left(\begin{array}{cccc}
-0.4 & 0.2 & -0.6 & -0.6 \\
0.2 & -0.2 & -0.2 & -0.2 \\
-0.2 & -0.2 & -0.2 & 0.2 \\
0 & -0.4 & 0.2 & -0.2
\end{array}\right)
$$

From the decision matrix $\xi$ we can get the optimization model:

$$
\left\{\begin{array}{l}
\max \omega=-0.4 \omega_{1}-0.6 \omega_{2}-0.8 \omega_{3}-0.8 \omega_{4} \\
\text { s.t } \omega_{i}=W, \quad \sum_{i=1}^{4} \omega_{i}=1, \omega_{i} \geq 0, i=1,2,3,4
\end{array}\right.
$$

Solving the optimization model we get $\omega=(1,0,0,0)$, thereby, calculate the formula $e_{i}=\xi \omega$ and get $e_{1}=-0.4, e_{2}=0.2, e_{3}=-0.2, e_{4}=0$. Which means the sorting order of the 4 CAI courseware is $X_{2}>X_{4}>X_{3}>X_{1}$, and the optimal CAI courseware is $x_{2}$.

\section{CONCLUSION}

The paper introduced intuitionistic fuzzy theory into the application of evaluation of CAI courseware, established a new comprehensive evaluation model for CAI courseware based on intuitionistic fuzzy theory, which can carry out a comprehensive evaluation of CAI courseware objectively and accurately, so that reduced the human interference factors during CAI courseware evaluation, and provide a strong guarantee for the development and utilization of CAI courseware and assurance of teaching quality.

\section{REFERENCES}

[1] He K K. Computer aided education[M]. Beijing: Higher education press, 1997.

[2] Zhang J P. Modern educational theory and Its application[M]. Beijing: Higher education press, 1997.

[3] Liu H Y, Wang W J. Evaluation system of CAI Courseware and AHP colligate evaluation[J]. Journal of e-education research, 2003, (7): 61-63.

[4] Wang W J. A Method of Appraisal System of Courseware and Analytic Hierarchy Process[J]. Journal of Gansu Education College (Natural Sciences), 2004, 18(2): 30-32.

[5] Bai J C, Yang Y. An Evaluation Method of CAI Coursewares[J]. Journal of computer development, 1999, 2: 25-27.

[6] Zhou G H, Huang W P. CAI courseware evaluation system and uncertain evaluation $[\mathrm{J}]$. Journal of Computer Systems \& Applications, 1995, 3: 32-35.

[7] Chen $\mathrm{X}$ F. Application of comprehensive evaluation in CAI coursewares[J]. Journal of shaoxing university, 2002, 22(1): 118-120.

[8] Jin C. Synthetic Evaluation and Research on CAI Software[J]. Journal of Computer Engineering, 2002, 28(3): 237-239.

[9] Zhao Y M, Jin G, Zhang Z H. CAI Courseware Design and Evaluation [J]. Journal of China e-education, 2003(6): 58-60.

[10] Wang J. Establishment of computer multimedia courseware quality assessment system[J]. Journal of Chinese Vocational and Technical Education, 2004, 21: 39-41.

[11] Atanassov K. Intuitionistic fuzzy sets[J]. Fuzzy sets and systems, 1986, 20(1): 87-96.

[12] $\mathrm{Xu} \mathrm{Z} \mathrm{S.} \mathrm{Intuitionistic} \mathrm{fuzzy} \mathrm{information} \mathrm{integration} \mathrm{theory} \mathrm{and}$ applications[M]. Beijing: Science press, 2008.

[13] Wu X H, Zhang J P.Multimedia Courseware Evaluation System research $[\mathrm{C}]$. Tenth academic papers of computers and education, Dalian: Dalian university of technology press, 2001: 349-353.

[14] Yager R R,Kacprzyk J. The Ordered Weighted Averaging Operators: Theory and Applications[M]. Norwell: Kluwer Academic Publishers, 1997. 